Marta Gontarz

doktorantka Uniwersytetu Kardynała Stefana Wyszyńskiego w Warszawie

\title{
HAZARD JAKO FAKT SPOŁECZNY (WSPÓŁCZESNE ODSŁONY)
}

\author{
Hazard as a social fact (the contemporary views)
}

\begin{abstract}
Streszczenie
W artykule przedstawiono hazard jako fakt i zjawisko społeczne w odniesieniu do koncepcji faktu społecznego Emila Durkheima. Omówiono wybrane definicje hazardu, jego różne rodzaje, tj. hazard rekreacyjny, ryzykowny, problemowy i patologiczny, wskazując różnice pomiędzy grą a hazardem. Na podstawie dostępnych badań scharakteryzowano styl życia i typowe zachowania osób uzależnionych od hazardu oraz współuzależnionych. Tytułowe zagadnienie ukazano w kontekście filozofii Georga Simmla, który twierdził, że w nowoczesnych społeczeństwach pieniądz stał się jedną z najważniejszych przyczyn alienacji jednostek.
\end{abstract}

Słowa kluczowe: fakt społeczny, hazard, hazard patologiczny, uzależnienie od hazardu, gry hazardowe

\begin{abstract}
The article presents gambling as a social fact and phenomenon in relation to Emil Durkheim's concept of social fact. Selected definitions of gambling were discussed, its various types, i.e. recreational, risky, problem and pathological gambling, indicating differences between gambling and games. Based on the available research, the lifestyle and typical behaviors of gambling addicts and co-addicts have been characterized. The title issue was presented in the context of the philosophy of Georg Simmel, who claimed that in modern societies money has become one of the most important causes of alienation of people.
\end{abstract}

Keywords: social fact, gambling, pathological gambling, addiction to gambling, gambling games

\section{Wprowadzenie}

Czy zjawisko hazardu może być ujmowane jako fakt społeczny? A jeśli tak, to jakie są zasadnicze cechy jego przemian w kontekście historycznym i społecznym?

Kategoria faktu społecznego, prekursorska wobec pojęcia kultury, pojawiła się po raz pierwszy w pracach twórcy paradygmatu socjologii normatywnej Emila Durkheima. Fakt społeczny to wszelki sposób postępowania, utrwalony lub nie, zdolny do wywierania na jednostkę zewnętrznego przymusu, „taki, który jest w danym społeczeństwie powszechny, mając jednak własną egzystencję, niezależną od jego jednostkowych manifestacji” (Durkheim 2000: 41). W ujęciu Durkheimowskim fakty społeczne mają trzy podstawowe cechy: powszechność (przekonania i reguły są podzielane przez członków pewnej zbiorowości), zewnętrzność (fakty społeczne istniały już wcześniej i zostały przekazane jednostkom w procesie socjalizacji) i przymusowość (każdy członek danej zbiorowości musi zachowywać się zgodnie z przyjętymi przez nią zasadami, przeciwstawienie się normom uruchamia mechanizm sankcji społecznych) (Durkheim 2000: 27, 41).

Pojęcie kultury zrodziło się jako efekt dwóch obserwacji fundamentalnych właściwości życia społecznego. Pierwsza z nich dotyczyła ogromnego zróżnicowania sposobów życia ludzi, a więc właśnie, w najogólniejszym sensie, kultur - w dawnych epokach, a także współcześnie - na kuli ziemskiej. W konkluzji obserwacji historycznych i współczesnych należy stwierdzić, że nie ma jednego społeczeństwa ludzkiego, lecz istnieje 
wielość społeczności ludzkich, z których każda wytwarza swoisty sposób życia, dla niej naturalny i oczywisty. Co więcej, w jednej i tej samej społeczności swoiste sposoby życia dziedziczone są pokoleniowo, a przez to zachowują ciągłość ponadjednostkową, wykraczającą poza okres życia poszczególnych członków. Fernand Braudel (1999) nazywał je strukturami długiego trwania, dotyczą one kodów mentalnych i obyczajowych, na ogół nieuświadamianych, ale podlegających transmisji pokoleniowej przede wszystkim przy udziale grup pierwotnych. Równocześnie pojawiają się innowacje prowadzące do zmian, współcześnie wyraźnie przyśpieszonych. Drugie spostrzeżenie, które prowadziło do zidentyfikowania kategorii kultury, było udziałem zwykłych ludzi żyjących w społeczeństwie. Otóż żyli oni w otoczeniu innych ludzi, z którymi nawiązywali kontakty, wchodzili w interakcje, budowali stosunki społeczne. Jednak doznawali z ich strony pewnych ograniczeń własnej swobody działania. Nie zawsze mogli postępować tak, jak by chcieli, nie zawsze mogli mówić to, co myśleli, ba, czasem nawet nie ośmielali się pomyśleć o pewnych rzeczach inaczej, niż było przyjęte, a to dlatego, że w ich środowisku tak się nie postępowało, tak się nie mówiło i tak się nie myślało. Społeczność była gotowa bardziej lub mniej bezwzględnie wymagać uznanych sposobów działania, mówienia i myślenia od swoich członków. Z perspektywy jednostki istnieje jakaś rzeczywistość wobec niej zewnętrzna, z którą zderza się nieustannie każdy, kto pragnie realizować swoje czysto indywidualne, autonomiczne, egoistyczne dążenia czy zachcianki. Jednostka, poddana presji społecznych oczekiwań, jest pozbawiona części swojej wolności (Berger 2007).

Pojęcie kultury (choć potocznie kojarzy się z kulturą narodową, np. polską, francuską, niemiecką) odnosi się do sposobów życia społeczności w każdej skali, od rodziny do ludzkości. Wszelkie grupy społeczne wytwarzają, mniej lub bardziej złożoną, własną kulturę grupową. Dla przykładu każda rodzina ma swoje zwyczaje, sposoby zwracania się do siebie, przezwiska, symbole, pamiątki. Swoiste obyczaje wytwarza wspólnota lokalna (Sztompka 2002: 230). Przez wartości rozumie się czasami reguły nadrzędne, fundamentalne, dotyczące spraw o najwyższym znaczeniu, których konkretnymi implikacjami są normy regulujące sprawy bardziej przyziemne. Stosunek obu pojęć bywa hierarchiczny, niemniej mogą być one traktowane równorzędnie, ulokowane na jednym poziomie i znamionujące pewną logiczną sekwencję ludzkich starań i ich efektów. Normy i wartości mogą być formułowane dwojako: w sposób pozytywny jako nakazy oraz w sposób negatywny jako zakazy. Piotr Sztompka zauważa, że pierwszym odpowiadają oczekiwania społeczne, które wyrażamy słowem „musi”, a drugim oczekiwania wyrażane słowem „nie może” lub „nie wolno” (2002: 231). Wszelkie przekroczenia tego typu regulacji traktowane są jako formy zachowań dewiacyjnych.

Zjawisko hazardu może być traktowane jako dewiacja, w ścisłym znaczeniu jako kategoria podnormalności, która pociąga za sobą zastosowanie w ramach kontroli społecznej sankcji o charakterze negatywnym. Zdaniem Andrzeja Siemaszki dewiacja odgrywa jedną z podstawowych ról w społeczeństwie. Wyznacza jego zewnętrzne granice, określa specyficzny charakter jego wewnętrznej struktury i stanowi ramy odniesienia, w obrębie których członkowie grupy rozwijają poczucie swojej tożsamości kulturowej. Przestępczość oraz inne formy dewiacji są, z punktu widzenia systemu społecznego, nie tylko nieuchronne, ale nawet pożądane. Społeczeństwo nie może istnieć bez sfery zachowań określanych jako subnormalne ${ }^{3}$ (Siemaszko 1993: 28-29). Ten punkt widzenia podzielał funkcjonalista Robert Merton. W świetle jego koncepcji hazard należy do kategorii działań innowacyjnych, w wypadku których osiągnięcie celu kulturowego (np. zdobycie dużej sumy pieniędzy) łączy się z zastosowaniem środków (działań) o charakterze nienormatywnym. Hazard, a zwłaszcza pewne jego odmiany, narusza akceptowane wzory zachowań i przyczynia się do społecznej dezintegracji poprzez zaburzenie ładu społecznego na poziomie jednostkowym (uzależnienie) i mikrostrukturalnym (dysfunkcjonalność życia rodzinnego i sieci lokalnych) (Merton 1982: 185).

\section{Sposoby definiowania hazardu}

Słowo „hazard” pochodzi z języka arabskiego (az-zahr) i oznacza grę w kości. Hazard jest formą rozrywki mającą na celu sprawdzenie siebie (w rywalizacji z losem) jednej lub większej liczby osób. W zabawie stawką

3 Niektórzy badacze, np. Florian Znaniecki (1974), eksponowali także nadnormalność (supranormalność) jako formę dewiacji. Zachowania tego typu łączące się z ofiarnością i heroizmem podlegają mechanizmowi wyróżnienia społecznego (sublimacji). 
są pieniądze lub inne dobra materialne, co ma wpływ na popularność tej formy uciechy, która kreuje przed graczami wizję wzbogacenia się (Niewiadomska, Lelonek, Brzezińska 2005: 10). Na ogół przez hazard rozumie się gry lub zakłady, w których stawką są pieniądze. To ryzykowne przedsięwzięcie, którego wynik zależy od przypadku (Lelonek-Kuleta 2012: 12).

Systemy religijne traktują hazard w sposób nieufny, a najczęściej uznają go za naganny. W judaizmie kwestia hazardu nie jest poruszana bezpośrednio ani w Torze, ani w Talmudzie. Stosunek do hazardu wyznacza zasada, że jest on dopuszczalny, ale tylko w granicach rozsądku, natomiast hazard przybierający postać uzależnienia jest sprzeczny z zasadami etycznymi. W Talmudzie granie na pieniądze postrzegane jest jako złodziejstwo (Woronowicz 2012: 79). W tym miejscu warto wskazać na moralne i religijne konotacje zjawiska hazardu. Katechizm Kościoła katolickiego wyjaśnia, że gry hazardowe (karty) bądź zakłady nie są same w sobie sprzeczne ze sprawiedliwością. Stają się moralnie nie do przyjęcia, gdy pozbawiają osobę tego, czego jej koniecznie trzeba do zaspokojenia potrzeb swoich potrzeb i innych osób. Namiętność do gry może stać się groźnym zniewoleniem. Nieuczciwe zakłady bądź oszukiwanie w grach stanowią poważne wykroczenie, chyba że wyrządzona szkoda jest tak mała, że ten, kto ją ponosi, nie mógłby w sposób uzasadniony uznać jej za znaczącą (Katechizm Kościota katolickiego 1994: 543). Omówiony fragment Katechizmu Kościota katolickiego wskazuje w istocie na obszary negatywnego oddziaływania patologicznego hazardu (m.in. zdrowotny, rodzinny, kulturowy, ekonomiczny), a także na jego kryminogenność i wiktymogenność.

Powyższe próby zdefiniowania zjawiska hazardu określają przesłanki, jakie muszą spełniać działania, aby zostały w ten sposób zakwalifikowane. Z przytoczonych definicji wynika, że hazard można traktować jako jeden z problemów społecznych, który dotyka osób w różnym wieku, pochodzących ze wszystkich warstw społecznych. Krzysztof Frysztacki definiuje problem społeczny jako „warunki, które zostały zdefiniowane przez znaczące grupy w obrębie populacji jako odstępstwo od lub złamanie pewnych społecznych standardów, które w przekonaniu tych grup muszą być podtrzymywane, jeśli ludzkie życie, czy porządek działań i wydarzeń wyznaczający i utrzymujący sens życia, mają nadal trwać" (2009: 17). Według Thomasa J. Sullivana i Kenricka S. Thompsona (1994: 6) z problemem społecznym mamy do czynienia w przypadku, gdy wpływowa grupa definiuje warunki społeczne jako zagrażające jej wartościom, a także jeśli dane warunki dotykają wielu osób i gdy można je przezwyciężyć dzięki działaniom zbiorowym. Wskazywanie znaczenia definiujących grup oraz dużych zbiorowości obejmowanych poszczególnymi zjawiskami jest głównym czynnikiem odróżniającym problemy społeczne od trudności indywidualnych i spraw prywatnych. Z kolei wartości są rozumiane w sensie podstawowym jako idee mówiące o tym, co jest dobre, a co złe, słuszne bądź błędne (Frysztacki 2009: 19).

Należy wskazać na różnice pomiędzy grą a hazardem. Gra sama w sobie nie jest zła, jeśli jest formą przypadkowej zabawy i nie wiąże się z utratą dużej sumy pieniędzy. Staje się niebezpieczna wtedy, gdy gracz traci kontrolę nad swoim zachowaniem, co w konsekwencji prowadzi m.in. do zaburzenia więzi rodzinnych, problemów zawodowych, niepowodzeń szkolnych lub zawodowych, zaburzeń relacji interpersonalnych, osamotnienia i dużych strat materialnych. Należy podkreślić, że znaczną lub decydującą rolę w grach odgrywa przypadek. Uzależnienie od gier hazardowych może stać się groźnym zniewoleniem, które skutkuje brakiem szacunku do samego siebie i zaburzeniami relacji społecznych.

Badacze zjawiska zwracają uwagę na podstawowe odmiany hazardu, takie jak: hazard rekreacyjny (rozrywka, forma spędzania czasu wolnego), ryzykowny (negatywne skutki gier są na tyle małe, że gracz potrafi się z nimi uporać), problemowy (pojawiają się pierwsze negatywne konsekwencje grania) i hazard patologiczny (uzależnienie z wszelkimi jego konsekwencjami) (Woronowicz 2012: 67).

\section{Hazard jako uzależnienie i dewiacja jednostkowa}

Należy podkreślić, że udział w grach zaczyna się bardzo niewinnie, gdy przypadkowy uczestnik dysponuje wolnym czasem i pieniędzmi. Na początku chodzi tylko o zabawę, chęć zaistnienia, zaimponowania innym. Korzyść finansowa nie jest ważna. Dopiero wygrana wywołuje chęć skorzystania z kolejnej szansy (Warmuz, Kolesiak 2017: 220). Na podstawie badań prowadzonych przez Centrum Badania Opinii Społecznej (CBOS) i na Katolickim Uniwersytecie Lubelskim Jana Pawła II (KUL) można stwierdzić, że skłonności do hazardu pojawiają się już w dzieciństwie i występują częściej u chłopców niż u dziewcząt. Gra w remika z dziadkiem 
lub obstawianie totolotka czy kupowanie zdrapek wspólnie z rodzicami jest powszechnym sposobem spędzania wolnego czasu. Osiągane korzyści stanowią jednak czynnik zagrażający i mogą wpływać na pojawienie się kłopotów z hazardem w dorosłym życiu. Obecność takich praktyk w najbliższym otoczeniu dziecka ma znaczenie w kontekście jego przyszłej aktywności.

Chociaż terminem „uzależnienie” najczęściej posługują się psychologowie, to jednak rzeczywistość uzależnienia jako przedmiot analizy jest bliska również socjologom. Wynika to z faktu, że uzależnienia, jeśli nie bezpośrednio, to przynajmniej w swoich uwarunkowaniach i skutkach, wychodzą poza sferę intrasubiektywną, dotykają interakcji z innymi ludźmi, tworzących materię życia społecznego. Socjolog sytuuje uzależnienia w kategorii dewiacji, czyli społecznego problemu, społecznej dezorganizacji, patologii, podkultury albo postępowania odbiegającego od normy. Ponad 100 lat temu Durkheim twierdził, że dewiacja jest nie tylko nieuchronna, lecz także pożądana ze względu na swoje reintegrujące społecznie konsekwencje. Z kolei Merton uważał, że dewiacja nie tyle wynika z natury człowieka, ile rodzi ją społeczeństwo. We właściwie funkcjonującym społeczeństwie cele i środki realizacji powinny być ze sobą ściśle powiązane (Petrykowska 2006: 14). Jednak jak pokazuje interpretacja koncepcji anomii Mertona, sytuacja taka w zasadzie nigdy nie ma miejsca, co więcej - w warunkach ponowoczesnych społeczeństw wartości i wzory kulturowe podlegają dyfuzji i daleko posuniętej relatywizacji, co utrudnia identyfikację przez jednostki zachowań o charakterze dysfunkcjonalnym.

Osoby uzależnione są pochłonięte hazardem, bardzo przeżywają każdą grę i absorbuje je planowanie kolejnych. Nie mogą przestać grać, w miarę możliwości zwiększają stawki, ciągle starają się odegrać straty, które poniosły, zaniedbują rodzinę, pracę, znajomych. Często się zdarza, że biorą udział w grze, chcąc uczcić jakiś sukces lub pocieszyć się po porażce. Hazardziści bardzo często tracą pieniądze zgromadzone wcześniej przez rodzinę, sprzedają cenne przedmioty lub pożyczają pieniądze, których następnie nie są w stanie zwrócić, co przysparza im wierzycieli i wciąga w spiralę długów (Tucholska 2008: 50). Sygnałem ostrzegawczym dla rodziny powinno być to, gdy bliski coraz więcej czasu spędza w barze, miewa kłopoty finansowe, pożycza pieniądze i kłamie. Osoby uzależnione często są spięte, drażliwe, miewają wahania nastrojów. W pewnym momencie pojawiają się u nich wyrzuty sumienia, depresja, poczucie bezradności. Na koniec przychodzi czas odcinania się od bliskich. Wygrana natomiast powoduje euforię, daje poczucie mocy i nadzieję, że szczęście już gracza nie opuści. Hazardziści często fantazjują wtedy o swoich wielkich wygranych. Snują wizje, co zrobią z pieniędzmi, planują wyjazdy, podróże, zakupy, inwestycje. Powtarzają sobie, że grają nie tylko dla siebie, lecz także dla bliskich.

Współuzależnionymi najczęściej są najbliżsi członkowie rodziny, np. żona, mąż, dzieci, rodzice lub partnerzy i przyjaciele. Osoba współuzależniona zazwyczaj widzi siebie i swoje życie wyłącznie przez pryzmat osoby uzależnionej, nie postrzega siebie jako osobnej istoty mającej własne życie. W ten sposób osoba uzależniona i współuzależniona stają się niewolnikami patologicznego hazardu. Wiara, że można mieć kontrolę nad osobą uzależnioną, że można hazardzistę zmusić, nakłonić, przekonać do zmiany zachowań, jest podstawowym złudzeniem osób współuzależnionych. Poświęcają one dużo czasu na poszukiwanie sposobów wpływania na hazardzistę. Brak rezultatu nie zmienia ich nastawienia, po chwilowym rozczarowaniu podejmują kolejne próby.

Zaburzenia więzi emocjonalnych w rodzinach są jedną z najważniejszych przyczyn uzależnień. Duże znaczenie mają również: deficyt rodzicielskich postaw w zakresie wyrażania uczuć, skłonność do emocjonalnego znęcania się, sztywność zasad, perfekcjonizm, zakaz poruszania z kimś z zewnątrz tematu problemów rodzinnych. Rodziny takie wywierają presję na swoich członków w kierunku zachowania lojalności kosztem poczucia zgodności z indywidualnym przeżywaniem rzeczywistości. W rodzinach dysfunkcyjnych panuje atmosfera emocjonalnego dystansu, chłodu uczuciowego. Brak możliwości wyrażania emocji może stać się istotnym czynnikiem doprowadzającym do uzależnień. Dziecko czuje się wyizolowane z istotnych relacji, a jego potrzeby - miłości, opieki, czułości i zrozumienia - pozostają niezaspokojone (Pierzchała 2009: 108).

W 1998 r. Światowa Organizacja Zdrowia wpisała uzależnienie od gier na listę chorób psychicznych w Międzynarodowej Klasyfikacji Chorób (ICD-10), określając je mianem: „zaburzenia polegającego na często powtarzającym się uprawianiu hazardu, który przeważa w życiu człowieka ze szkodą dla wartości i zobowiązań społecznych, zawodowych, materialnych i rodzinnych" (Silczuk, Habrat 2016: 90). W świetle badań 
prowadzonych przez (CBOS) oszacowanie liczby Polaków cierpiących z powodu patologicznego hazardu nie jest proste. Liczba leczonych z rozpoznaniem „hazard patologiczny” jest zapewne o wiele mniejsza niż rzeczywista liczba uzależnionych i nie oddaje skali zjawiska. Podobnie jak w przypadku innych uzależnień, ludzie szukają pomocy medycznej w ostateczności, żeby uniknąć stygmatyzacji związanej z podjęciem takiej aktywności. Dodatkowo leczenie patologicznego hazardu jest jeszcze w Polsce słabo rozwinięte, a dostępność nowoczesnych, wyspecjalizowanych form - niewielka (CBOS 2015: 77).

Należy zaznaczyć, że kobiety znacznie częściej niż mężczyźni wstydzą się swojego uzależnienia. Podłoże tego uzależnienia jest zawsze takie samo - hazard to choroba uczuć wynikająca z nieumiejętności radzenia sobie z emocjami. U każdego przyczyna może być inna, ale u kobiet najczęstszym powodem jest niskie poczucie własnej wartości i zła samoocena. Gra pomaga poczuć się lepiej tylko na początku, koniec może być katastrofalny w skutkach. Wiele hazardzistek podejmuje próby samobójcze. Problem hazardu wśród kobiet jest wciąż mało nagłośniony, ale coraz bardziej powszechny, podobnie jak uzależnienie od alkoholu.

Liczba samobójstw jest większa wśród hazardzistów niż wśród alkoholików. Stres spowodowany długami, a w związku z tym często i kłopotami z rodziną, a nawet z prawem, bywa nie do zniesienia. $Z$ czasem to, co miało być zabawą, staje się obsesją. Duża przegrana może doprowadzić do pojawienia się stanów depresyjnych oraz myśli samobójczych. Specjaliści nazywają to fazą utraty nadziei - czwartym i ostatnim etapem rozwoju uzależnienia. Twierdzą, że pozostają wtedy tylko cztery wyjścia: ucieczka w alkohol i leki, więzienie, śmierć samobójcza lub z rąk wierzycieli albo - zwrócenie się o pomoc.

\section{Społeczno-demograficzny profil uczestników gier hazardowych}

Jak wynika z badań przeprowadzonych w 2010 r. przez Centrum Informacji o Narkotykach i Narkomanii Krajowego Biura ds. Przeciwdziałania Narkomanii (CINN KBPN) oraz badań z 2010 i 2013 r. zrealizowanych wśród młodzieży szkolnej przez Fundację CBOS oraz KBPN wśród młodzieży i młodych dorosłych (15-24 lata), w gry hazardowe grało 38,9\% dziewcząt i kobiet oraz 50,3\% chłopców i mężczyzn. Najmłodsza badana populacja, czyli osoby w wieku 15-24 lata, grała rzadziej w Lotto (18,8\%). Natomiast w loteriach i innych grach/loteriach SMS-owych udział brał co piąty badany w wieku 15-64 lat (18,7\%), podobny odsetek (19,1\%) dotyczył grupy 15-24-latków. W grach SMS-owych nieznacznie częściej uczestniczyły kobiety $(20,4 \%)$ niż mężczyźni (16,7\%), a do obstawiania zakładów bukmacherskich przyznało się 8,4\% respondentów w wieku 15-64 lat oraz co dziesiąta młoda osoba w wieku 15-24 lat. Porównując młodzież (15--24 lata) z pozostałą populacją, można zauważyć mniejszą popularność Lotto, w przypadku innych rodzajów gier w obu grupach wiekowych obserwuje się zbliżone odsetki badanych (Malczewski 2014: 110).

Z badań Instytutu Psychiatrii i Neurologii (IPiN) przeprowadzonych w 2015 r. wynika, że prawie 9\% zbadanych nastolatków prezentuje problemowy sposób korzystania z hazardu. W grupie tej jest więcej chłopców (14\%) niż dziewcząt (3\%), także więcej uczniów szkół ponadgimnazjalnych (10\%) niż gimnazjalistów (5\%) w ten sposób korzysta z hazardu. Zarówno rodzice, jak i nastoletni uczestnicy potwierdzali, że najbardziej rozpowszechnionymi formami hazardu są gry na automatach, w Lotto i losy zdrapki, zakłady bukmacherskie, gra w pokera oraz gry hazardowe w Internecie. Najłatwiej dostępne są automaty, ponieważ prawo zakazujące dostępu do tych gier nieletnim nie zawsze jest przestrzegane. Ogólnie dostępne są także Lotto i losy zdrapki, choć jak podkreślali uczniowie, nieletni nie mogą samodzielnie odebrać wygranej. Okazało się, że Lotto jest formą hazardu, którą młodzież uprawia wraz z członkami rodziny. Rodzice i uczniowie uważali, że łatwy jest też dostęp do gier hazardowych przez Internet ze względu na niemożność zweryfikowania rzeczywistego wieku gracza (IPN 2015: 12). Natomiast z badań przeprowadzonych przez CBOS w 2017 r. wynika, że najpopularniejsze wśród młodzieży są zdrapki. Kupuje je trzech na pięciu $(64,5 \%)$ uczniów, przy czym co czwarty robi to kilka razy w miesiącu (25\%). Natomiast wśród dorosłych najbardziej popularne są gry liczbowe Totalizatora Sportowego, z których korzysta połowa odwiedzających kasyna internetowe (51\%). Wygrane najczęściej przeznaczane są na finansowanie dalszej gry, zarówno w przypadku tradycyjnego hazardu, jak i gier w Internecie (CBOS 2017: 60).

Interesujące są także rezultaty badań przeprowadzonych wśród osób w starszym wieku. Z raportu z badań Hazard w życiu seniorów opracowanego przez Krajowe Biuro ds. Przeciwdziałania Narkomanii KUL w 2017 r. 
wynika, że respondenci nie postrzegają gier liczbowych czy zdrapek jako formy hazardu. Wielu badanych za hazard uważa gry w kasynie, na automatach losowych i zakłady sportowe. Bardzo istotnym czynnikiem uprawiania hazardu przez seniorów jest pragnienie poprawienia sytuacji finansowej, czemu towarzyszy wiara w wygraną. Równie ważnym aspektem pozostają emocje. Większość starszych osób przeżywa dzięki grze silne, pozytywne emocje - adrenalina, ekscytacja, fascynacja, przyjemność, euforia towarzyszą oczekiwaniu na wygraną. Gry hazardowe mają również negatywne skutki w życiu seniorów, prowadzą np. do rozpadu rodziny, problemów finansowych czy zerwania relacji ze znajomymi (KUL 2017: 104-108).

Pragnienie posiadania pieniędzy przez człowieka łączy się ze zmianą sposobu myślenia, co stało się szczególnie istotne dla członków nowoczesnych społeczeństw. W zmieniającej się rzeczywistości nastawionej na konsumpcję jednostka ulega atrakcjom rynku, jest żądna coraz to nowych wrażeń, emocji i przyjemności. Współczesny człowiek zaspokaja nie tyle swoje potrzeby, ile zachcianki. Należy zaznaczyć, że konsumpcjonizm to poważny problem społeczny i wychowawczy, m.in. dlatego, że odwodzi człowieka od wyższych wartości, odnoszących się do sensu życia. Przykładem jest patologiczny hazard. „Nie istnieje wyraźniejszy symbol absolutnie dynamicznego charakteru świata niż pieniądz. Znaczenie pieniądza polega na tym, że się go wydaje" - pisał Simmel (1997: 486). Pieniądz sam w sobie jest mechanicznym odbiciem stosunków wartości rzeczy. Wybitny socjolog konstatował, że w obszarze interesów i usług rynkowych wszyscy ludzie są traktowani na równi, gdyż poddają się mocy pieniądza (Simmel 1997: 406). W przypadku gier hazardowych pieniądze odgrywają zasadniczą rolę - z jednej strony umożliwiają udział w grze, z drugiej - gra daje nadzieję na wzbogacenie się. Można wskazać, że kluczowym czynnikiem uprawiania gier hazardowych, oprócz dostarczanych emocji i wrażeń, są wygrywane lub przegrywane pieniądze. Już na początku ubiegłego wieku Simmlowi towarzyszyła świadomość powiązania znaczenia pieniądza z relatywistycznym stylem życia oraz tego, że zyski, jakie ludziom przyniosło oswobodzenie od idei absolutnych, nie równoważą kosztów: „Pieniądz jest jedynie środkiem, materiałem albo przykładem służącym do przedstawienia powiązań, które zachodzą między najbardziej zewnętrznymi, realistycznymi, przypadkowymi zjawiskami a najbardziej idealnymi potencjałami istnienia, najgłębszymi prądami indywidualnego życia oraz historii. Sens całości jest wyłącznie taki, by pociągnąc linię łączącą powierzchniowy obszar zjawisk ekonomicznych z ostatecznymi wartościami i znaczeniami wszystkiego co ludzkie" (Simmel 1997: 11). Konsekwencją rozwoju gospodarki pieniężnej, szczególnie w jej wymiarze ponowoczesnym (m.in. wirtualnym), jest postępująca alienacja jednostek ludzkich.

Wydawanie pieniędzy można podzielić na dwie kategorie: zawierające ryzyko oraz niezawierające ryzyka. Z jednej strony należy się liczyć z możliwością utraty znacznych środków, które podlegają grze spekulacyjnej, a z drugiej strony trzeba przyznać, że nawet najsolidniejszy sposób zarabiania pieniędzy może nieść ze sobą pewne ryzyko. Czynniki obiektywne wyznaczające prawo do podjęcia ryzyka nie działają. Fakt, że za pomocą niewielkiej sumy pieniędzy można osiągnąć spektakularny zysk, powoduje, że wielu ludzi zapomina o tym, iż ich sytuacja nie pozwala im nawet na takie ryzyko. Pokusom takim najczęściej poddawani są ludzie, których dochód zapewnia jedynie minimum egzystencji i w związku z tym nie powinni w ogóle ryzykować (Simmel 1997: 233). W przypadku patologicznego uprawiania gier hazardowych mamy do czynienia z bardzo dużym ryzykiem m.in. utraty pieniędzy, rodziny, pracy, znajomych. Proces rozpoczyna się w momencie przegrania pieniędzy, majątku, następnie gracz jest zmuszony do pożyczania pieniędzy czy w konsekwencji kradzieży i rozboju. Kolejnym etapem zazwyczaj jest utrata pracy, szkoły, rodziny, przyjaciół, jak również nieuchronność zejścia na złą drogę, czyli działanie niezgodnie z prawem.

\section{Uwagi końcowe}

Zjawisko hazardu, które towarzyszy człowiekowi od tysięcy lat, uległo transformacji w związku z tym, że stał się on powszechnie dostępny. Jak wynika z badań CBOS przeprowadzonych w 2015 r., w Polsce dwie trzecie hazardzistów mieszka na wsi lub w małych miastach. Może to świadczyć o tym, że hazard staje się ważnym elementem stylu życia w małych społecznościach, m.in. w związku z brakiem innych rozrywek. Dla przykładu gra w kasynie lub obstawianie zakładów podczas wyścigów konnych budzi skojarzenia ze stylem życia ludzi zamożnych, natomiast inne gry, takie jak: totolotek, zdrapki, konkursy SMS-owe czy gry na automatach są powszechnie dostępne dla osób w różnym wieku, o różnym statusie materialnym i wykształceniu. 
Upowszechnianie w znacznej mierze wśród młodzieży wiedzy na temat uzależnienia od hazardu jest konieczne, ale należy również edukować seniorów, zwłaszcza w kontekście ryzyka związanego z uprawianiem hazardu przez młodych oraz roli dorosłych członków rodziny w kształtowaniu właściwych postaw. W celu ograniczenia dostępności gier niezwykle ważne jest monitorowanie skutków wprowadzonych rozwiązań prawnych. Trzeba mieć nadzieję, że nowelizacja przepisów dotyczących urządzania gier hazardowych w Polsce w znaczny sposób uniemożliwi udział osób nieletnich w grach. Należy podkreślić, że problem uzależnienia dotyczy nie tylko grających, lecz także członków rodziny i osób z najbliższego otoczenia (współuzależnionych).

Hazard we współczesnych społeczeństwach ujmowany jest przede wszystkim jako zjawisko o charakterze dewiacyjnym, a zarazem przejaw społecznej patologii. Z drugiej strony pewne jego formy mogą stanowić (podobnie jak w przeszłości) elementy „próżniaczego” stylu życia, odróżniającego od siebie klasy czy grupy społeczno-zawodowe (Veblen 2008). Podstawowe wektory zmian łączą się z coraz większą inkluzywnością tego fenomenu, jego umasowieniem, utowarowieniem i włączeniem w obieg globalny. Służą temu nowoczesne technologie (także Internet), umożliwiające korzystanie z usług hazardowych coraz młodszym generacjom, co dzieje się niejednokrotnie poza kontrolą dorosłych.

\section{Bibliografia}

Berger P. (2007), Zaproszenie do socjologii (tłum. J. Stawiński). Warszawa: Wydawnictwo Naukowe PWN. Braudel F. (1999), Historia i trwanie (tłum. B. Geremek). Warszawa: Czytelnik.

CBOS (2015), Oszacowanie rozpowszechnienia wybranych uzależnień behawioralnych oraz analiza korelacji pomiędzy występowaniem uzależnień behawioralnych a używaniem substancji psychoaktywnych. Raport końcowy. Warszawa: Centrum Badania Opinii Społecznej.

CBOS (2017), Nastolatki w sieci hazardu: pogtębiona analiza zjawiska hazardu online z perspektywy grających nastolatków jako grupy szczególnie narażonej na zagrożenia będące jego skutkiem. Warszawa: Centrum Badania Opinii Społecznej.

Durkheim E. (2000), Zasady metody socjologicznej, cz. 1 (tłum. J. Szacki). Warszawa: Wydawnictwo Naukowe PWN.

Frysztacki K. (2009), Socjologia problemów spotecznych. Warszawa: Wydawnictwo Naukowe Scholar.

IPiN (2015), Czynniki zwiazane z hazardem, kompulsywnymi zakupami oraz nadużywaniem Internetu wśród mtodzieży w wieku $12-19$ lat. Warszawa: Instytut Psychiatrii i Neurologii. Zakład Zdrowia Publicznego. Pracownia Profilaktyki Młodzieżowej „Pro-M”.

Katechizm Kościota katolickiego (1994). Poznań: Pallotinum.

KUL (2017), Raport z projektu badawczego „Hazard w życiu seniorów”. Lublin: Katolicki Uniwersytet Lubelski Jana Pawła II.

Lelonek-Kuleta B. (2012), Psychospoteczne korelaty uzależnień od gier hazardowych. Lublin: Towarzystwo Naukowe Katolickiego Uniwersytetu Lubelskiego.

Malczewski A. (2014), Uczestnictwo mtodzieży i mtodych dorostych w grach hazardowych [w:] J. Jarczyńska (red.), Uzależnienia behawioralne i zachowania problemowe mtodzieży: teoria, diagnoza, profilaktyka, terapia. Bydgoszcz: Wydawnictwo Uniwersytetu Kazimierza Wielkiego, s. 109-120.

Merton R. (1982), Teoria socjologiczna i struktura spoteczna (tłum. E.T. Morawska, J. Wertenstein-Żuławski). Warszawa: Państwowe Wydawnictwo Naukowe.

Niewiadomska I., Lelonek B., Brzezińska M. (2005), Hazard. Lublin: Gaudium.

Pierzchała K. (2009), Nieprawidtowe postawy rodzicielskie przyczyna ryzykownych zachowań dzieci i mtodzieży [w:] K. Pierzchała, C. Cekiera, Cztowiek a patologie spoteczne. Toruń: Wydawnictwo Adam Marszałek, s. 99-142.

Petrykowska M. (2006), Patologia spoteczna - próba definicji problemu [w:] M. Jędrzejko (red.), Patologie spoteczne. Pułtusk: Wyższa Szkoła Humanistyczna im. A. Gieysztora, s. 13-40.

Sullivan T.J., Thompson K.S. (1994), Introduction to Social Problems. New York: Macmillan Publishing Company. 
Siemaszko A. (1993), Granice tolerancji - o teoriach zachowań dewiacyjnych. Warszawa: Wydawnictwo Naukowe PWN.

Silczuk A., Habrat B. (2016), Zaburzenia uprawiania hazardu [w:] B. Habrat (red.), Zaburzenia uprawiania hazardu i inne tak zwane natogi behawioralne. Warszawa: Instytut Psychiatrii i Neurologii, s. 83-218.

Simmel G. (1997), Filozofia pieniadza (tłum. A. Przyłębski). Poznań: Wydawnictwo Fundacji Humaniora. Sztompka P. (2002), Socjologia. Analiza spoteczeństwa. Kraków: Znak.

Tucholska S. (2008), Zjawisko hazardu patologicznego i jego uwarunkowania. „Roczniki Psychologiczne” $11(2)$, s. 45-68.

Warmuz D., Kolesiak I. (2017), Uzależnienie od hazardu kryzysem jednostki i rodziny. „Perspectiva. Legnickie Studia Teologiczno-Historyczne" 16(1), s. 217-234.

Woronowicz B.T. (2012), Hazard, historia, zagrożenia i drogi wyjścia. Poznań: Media Rodzina.

Veblen T. (2008), Teoria klasy próżniaczej. Warszawa: Muza.

Znaniecki F. (1974), Ludzie teraźniejsi a cywilizacja przysztości. Warszawa: Państwowe Wydawnictwo Naukowe. 